\title{
Arap Dili Gramerini Dil-Toplum İlişkisi Üzerinden Okuma Denemesi
}

An Attempt to Read Arabic Grammar through Language-Society Relationship

\section{Rıfat AKBAȘ}

Dr. Öğr. Üyesi, Van Yüzüncü Yıl Üniversitesi, İlahiyat Fakültesi, Arap Dili ve Belagatı Anabilim Dalı, Assistant Professor, Van Yüzüncüyll University, Faculty of Theology, Departmant of Arabic Langauge and Rhetoric Van, Turkey akbasakbasa.1988@hotmail.com https://orcid.org/0000-0002-8533-3335

\section{Makale Bilgisi / Article Information}

Makale Türü / Article Types: Araştırma Makalesi / Research Article

Geliş Tarihi / Received: 15 Eylül / September 2020

Kabul Tarihi / Accepted: 28 Ekim / October 2020

Yayın Tarihi / Published: 15 Aralık / December 2020

Cilt / Volume: 11 Sayı / Issue: 25 Sayfa / Pages: 741-762

Atıf / Cite as: Akbaş, Rıfat. “Arap Dili Gramerini Dil-Toplum İlişkisi Üzerinden Okuma Denemesi [An Attempt to Read Arabic Grammar through Language-Society Relationship]". Şırnak Üniversitesi İlahiyat Fakültesi Dergisi - Şırnak University Journal of Divinity Faculty 11/25 (December 2020), 741-762. https://doi.org/10.35415/sirnakifd.795457

Etik Beyanı / Ethics Declaration: Bu makalede bilimsel araştırma ve yayın etiği ilkelerine riayet edilmiştir. Makale etik izin gerektirmeyen bir çalışma olup en az iki hakem tarafından incelenmiş ve intihal içermediği teyit edilmiştir./ In this article, the principles of scientific research and publication ethics are respected. The article is a study that does not require ethical permission. It has been reviewed by at least two referees and was confirmed that it did not contain plagiarism.

Copyright () Published by Şırnak Üniversitesi, İlahiyat Fakültesi / Şırnak, Türkiye (Şırnak University, Faculty of Divinity, Şırnak, 73000 Turkey). 
Öz

İnsanlar arasındaki iletişimin en önemli araçlarından biri olan dil, kendi içerisinde kanunları olan ve bir millete ait kültürün nesilden nesle aktarımını sağlayan canlı bir varlıktır. Sözcüklerin anlamlı bir cümle içindeki yapısıyla beraber şekil, işlev, sözdizimi, kök bilgisi ve üslûbunu ele alan gramer ise bu yönüyle dil için bir kalkan görevini görmektedir. Bu bakımdan tarih boyunca dinî ve edebî metinlerin doğru anlaşılması hedeflenerek dil eğitimi ve öğretimi gramer üzerinden gerçekleştirilmiş, dilin işlevi ve normları da bu sayede tespit edilmeye çalışılmıştır. İslâm coğrafyasında hicri birinci yüzyılın ikinci yarısından itibaren dil ile ilgili faaliyetler ve gramer çalışmaları da dinî ve edebî metin odaklıdır. Bu çalışmalar ile Arap toplumunun gündelik konuşmaları arasında sıkı bir ilişkinin var olduğu hususu makalenin ana temasını teşkil etmektedir. Bu bağlamda makalede Arap grameri ile gramerin ortaya çıktığı toplumun iç yapısı arasında söz konusu ilişkiyi destekleyen birtakım tespitlere alt başlıklar şeklinde yer verilmiştir. Makalede özellikle edebî veya dinî metinlerde bir dilin grameriyle birlikte tarihsel, toplumsal, bölgesel ve kültürel süreçlerinin de göz önünde bulundurulmasının önemi, verilen örneklerle vurgulanmaya çalışılmıştır. Zira bu tür metinlerin tarihsel süreci ve yazıldığı dilin bu süreçteki işlevinin göz ardı edilerek yorumlanması olası hataların önünü daha fazla açacaktır.

Anahtar Kelimeler: Arap Dili, Arap Grameri, Dil-Toplum İlişkisi, Dil-Kültür İlişkisi, Toplum Dili.

\begin{abstract}
Language, which is one of the most important means of communication between people, is a living entity that has laws in itself and ensures the transmission of a nation's culture from generation to generation. In particular, grammar, which deals with the structure of words in a meaningful sentence, form, function, syntax, root knowledge, and style, acts as a shield for the language in this respect. That's why throughout history, with the aim of understanding religious and literary texts correctly, language education and teaching have been carried out through grammar, and the function and norms of the language have been determined in this way. Since the second half of the first century in Islamic geography, activities related to language and grammar studies are focused on religious and literary texts. The main theme of the article is that there is a close relationship between these works and the daily speeches of Arab society. In this context, some findings supporting the relationship between Arabic grammar and the internal structure of the society where grammar emerged are included in the article as subheadings. The article tries to emphasize the importance of taking into account the grammar of a language, as well as its historical, social, regional, and cultural processes, especially in literary or religious texts. As a result, ignoring the historical process and the function of the language of such texts and interpreting them will pave the way for possible mistakes.
\end{abstract}

Keywords: Arabic Language, Arabic Grammar, Language-Society Relationship, LanguageCulture Relationship, Community Language. 


\section{Extended Abstract}

Language, one of the most important verbal transmission tools of culture, is a treasure of civilization as well as the mirror of a nation's history and its most important element showing its development. The relationship between the language and the society, which is formed by individuals who have a certain geographical location and who have a long-standing existence and have common grounds in many ways, is both necessary and natural. Thus, the general culture of individuals living in a society can only be seen into via the language they speak and write. Since the beginning of the twentieth century, this relationship has become scientific, especially with studies that focus on language via society and considered as "sociolinguistics".

It can be said that grammar, which deals with the sound, form, and sentence structure of a language to the finest detail and determines the rules of the language, acts as a shield for the language. In this respect, grammar can be defined as a branch of science that determines the expression styles spoken in the society, binds the rules, and ensures the functioning of the rules. There is always a danger that societies that do not make progress in this branch of science will disappear after a certain period of time. Therefore, the history of grammar in some civilizations dates back to the fifth and even the fourth century B.C. In Arabs, whose oral culture dates back to the Age of Ignorance, grammar reached its peak by making enviable advances in a relatively short period of time with the influence of the religion of Islam. A large part of these studies in the language perspective is particularly concerned with questions such as which social contexts individuals prefer and which and how well speech styles are compatible with the oral culture they live in. This reveals the obvious role of culture and society in determining language rules.

The most reliable sources that can shed light on the relationship between grammar and language-society in Arabic culture and provide us with reliable information on this matter are poetry journals and works of the writers and linguists in the classical period who bring the Quran to the foreground and interpret the language of society along with the principles of linguistics. Very important works were written in this field in the first periods, such as Garîbu'l-Kur'ân, in which the versatility of words, as well as the differences in lexicon and style, were taken as the basis and which aimed to make the Quran more understandable and I'râbu'l-Kur'âns, written mainly in nahiv, sarf and i'râb style along with detailed explanations of the strange words. In addition to this, books such as Ma'ânî'l-Quran and Mecâzu'l-Quran, in which both the lexical and style differences in the Garîbu'l-Qur'an and the nahiv and i'râb features in the I'râbu'l-Qur'an are meticulously handled and processed, were also compiled and the first cores of the linguistic tafsir tradition were thus created.

At the head of the poetry magazines are, el-Mufaddaliyyât, also known as Kitâbu'lIntiyârât and Kitâbu'l-Muhtârât, of Mufaddal b. Muhammed ad-Dabbi (d. 178/794); elAsma iyyât of Abdülmelik b. Kureyb al-Asmaî (d. 216/831); Cemheretu es'ari'l-Arab of Ebû Zeyd el-Kuresî who lived in the beginning of the Hijri fourth century, and al-Eganî of Ebu'lFerec el-Isfahânî' (d. 356/967).

When the works in question are examined, it is seen that the activities related to grammar, especially in the early periods, were not carried out specifically for a particular region, tribe and dialect, and were not left to the monopoly of individuals accepted as authorities in this science. One can easily come to this conclusion by examining the subjects addressed, the samples referenced and the individual analyzes made in the book of Sîbeveyhi and the works of linguists and literati of the early period which have come to the 
present day in a recorded form. In particular, when language scholars interpreted some verses, not only the grammatical rules were adhered to, but the expressions and usage styles used in Arab society were often referred to. In other words, the message that the holy book sent to a territory where the Arabs are located is not independent of their daily speech in terms of content and language is tried to be given through the grammatical and semantic analysis of some verses.

In this context, some findings supporting the relationship between Arabic grammar and the internal structure of the society in which grammar emerged are included in the article as subheadings. In the article, the importance of considering the grammar of a language as well as its historical, social, regional, and cultural processes, especially in literary or religious texts, is tried to be emphasized with the examples given. As a result, ignoring the historical process and the function of the language of such texts and interpreting them will pave the way for possible mistakes. On the other hand, in the examples discussed on the subject, the works of linguists and grammarians of the classical period were mostly used and, where deemed necessary, references were made to modern studies. The study adheres to the use of supportive explanations with linguistic commentaries as much as possible, and to a lesser extent, the ancient Arabic poems delivered on the basis of istishâd were also used. In fact, it is not even open to debate that words gain new meanings based on the acceptance of societies, and it would not be a rational approach to limit the source areas of Arabic grammar when there are unreasonable approaches and question marks that need to be answered at the point of trying to solve religious or literary texts from thousands of years ago. Therefore, attention should be paid not to detach ancient literary or sacred texts from the language culture of their periods, and care should be taken that grammatical, etymological, and semantic analyzes do not contradict the language spoken by the Arab society in particular and with socio-cultural dynamism in general. Besides, such approaches should not be considered as a compromise on grammar, but as utilizing a broad framework. On the other hand, avoiding the evaluation of Arabic grammar in this manner will not contribute to scientific development. On the contrary, approaches that are accepted only as a tribe, dialect, or common language will hamper the advancement of grammar-oriented linguistics, as well as narrowing the broad areas of use. 


\section{Giriş}

Bir medeniyet hazinesi olarak değerlendirilen dil, kültürün en önemli sözlü aktarım aracıdır. Bu yönüyle dil bir milletin tarihinin aynası olduğu gibi bir toplumun gelişmişliğini gösteren en önemli unsurudur. ${ }^{1}$ Bundan dolayı dili tarihinden ve hayat bulduğu toplumdan ayırmaya çalışan dilciler tenkit edilmiş ve basmakalıp ifadeleri tekrarlamakla suçlanmışlardır. ${ }^{2}$

Varlığını uzun süre devam ettiren, belli bir coğrafi konumu olan ve bir yaşam tarzını paylaşan bireylerden oluşan toplumun ${ }^{3}$ dil ile olan ilişkisi hem gerekli hem de doğaldır. $\mathrm{Bu}$ yüzden bir toplumda yaşayan bireylerin genel kültürü ancak konuştukları ve yazıya döktükleri dil ile kavranabilir. Yirminci yüzyılın başlarından itibaren özellikle dili toplum üzerinden konu alan ve "toplumdilbilim" (sosyolengüistik) adıyla telakki edilen çalışmalarla bu ilişki bilimsellik kazanmıştır.

Gramer ile dil arasındaki sıkı ilişkiyi “Ana dili, topluluk bilincini yansıtan, dünya görüşünü kalıplayan ulusal bir varlık, gramer de eğitimde bu varlığın en güçlü ve güvenilir koruyucusudur." 5 şeklinde açıklayan Agop Dilaçar'a göre gramer, dil için bir kalkan vazifesi görmektedir. Bu yönüyle gramer, toplumda konuşulan ifade tarzlarını tespit eden, kurallara bağlayan ve kuralların işleyişini sağlayan bir bilim dalı olarak tanımlanabilir.

Geçmişi M.Ö. beşinci hatta dördüncü yüzyıla kadar eskiye dayanan gramer ilmine Hintliler, Yunanlılar ve Bizanslıların önem verdikleri bilinmektedir. ${ }^{6}$ Sözlü kültürü Câhiliye dönemine kadar uzanan ${ }^{7}$ Araplar da ise gramer İslâm dininin etkisiyle kısa sayılabilecek bir zaman diliminde gıpta edilecek ilerlemeler kaydederek zirve noktasını görmüştür. ${ }^{8}$

Arap kültüründe gramer ve dil-toplum ilişkisine 1şı tutabilecek ve bu hususta bize sağlıklı bilgiler sunacak en güvenilir kaynakların başında şiir mecmuaları ve Kur'ân'ı Kerîm'i dilbilimin esaslarıyla beraber toplum dilini de ön plana çıkarıp bu şekilde bir yorumlamaya giden klasik dönem dilci ve edebiyatçıların eserleri gelmektedir ki bu alanda

1 Doğan Aksan, Her Yönüyle Dil: Ana Çizgileriyle Dilbilim (Ankara: Türk Dil Kurumu Yayınları, 2015), 13.

2 Mehmet Kaplan, Kültür ve Dil (İstanbul: Dergâh Yayınları 2019), 12, 147, 148.

Gülbahar Gül, "Birey Toplum Eğitim ve Öğretmen”, Hasan Ali Yücel Ĕ̆itim Fakültesi Dergisi 1, (2004), 224.

4 D. Hudson, İlmü'l-lügati'l-ictimâ'̂̂, çev. Mahmud Ayyâd (Kahire: Âlemü'l-Kutub, 1990), 12.

5 Agop Dilaçar, Gramer: Tanımı, Adı, Kapsamı, Türleri, Yöntemi, Ĕ̆itimdeki Yeri ve Tarihçesi (Ankara: Türk Tarih Kurumu Basım Evi, 1989), 123.

6 Dilaçar, Gramer: Tanımı, Adı, Kapsamı, 123.

7 Amr b. Bahr b. Mahbûb el-Câhiz, Kitâbü'l-Hayevân, thk. Abdusselâm Muhammed Hârûn (Misir: Mektebetu Mustafa el-Bâbi'l-Halebî, 1384/1965), 1/74.

8 Faruk Zeki Perek, Eski Çağda Dilbilgisi Araştırmaları: Gramerin Doğuşu (İstanbul: Edebiyat Fakültesi Basımevi, 1961), 2. 
oldukça önemli eserler kaleme alınmıştır. Örneğin ilk dönemlerde Kur'ân'ı Kerîm'in doğru anlaşılması hedeflenerek lügat ve üslûp farklılıklarının yanı sıra kelimelerin çok yönlülügüüün esas alındığı Garîbu'l-Kur'ân; garip kelimelerin detaylı açıklamalarıyla birlikte daha çok nahiv, sarf ve i'râb ağırlıklı I'râbu'l-Kur'ân'lar kaleme alınmıştır. Bununla birlikte hem Garîbu'l-Kur'ân'lardaki lügat ve üslûp farklılıkları, hem de I'râbu'l-Kur'ân'lardaki nahiv ve i'râb özelliklerinin titizlikle ele alınıp işlendiği Me'ânîll-Kur'ân ve Mecâzu'l-Kur'ân türü kitaplar da telif edilmiş ve dilbilimsel tefsir geleneğinin ilk nüveleri bu sayede oluşturulmuştur. ${ }^{9}$

Şiir mecmualarının başında ise Mufaddal b. Muhammed ed-Dabbî́nin (öl. 178/794) Kitâbü'l-İhtiyârât ve Kitâbü'l-Muhtârât isimleriyle de anılan el-Mufaddaliyyât'1, Abdülmelik b. Kureyb el-Asmaî' nin (öl. 216/831) el-Asma 'iyyât'ı, hicri dördüncü yüzyılın başlarında yaşamış olan Ebû Zeyd el-Kureşî’nin Cemheretü eş‘ari'l-Arab'1 ve Ebü'l-Ferec el-İsfahânî'nin (öl.

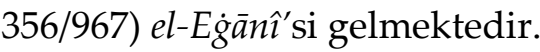

Binaenaleyh makalede gerek dilbilimsel tefsir gerekse şiir mecmuaları doğrultusunda gramer ve dil-toplum ilişkisine kanıt olabilecek örnekler, önemli şahsiyetler tarafından yapılan bireysel değerlendirmeler ve âyet yorumlarına alt başlıklar şeklinde yer verilecektir. Araştırmada dinî ve edebî metinlerin doğru bir şekilde anlaşılması noktasında gramer üzerinden yapılan uğraşıların toplum dili ve tarihsel süreç ile birlikte daha sağlıklı sonuçlar verebileceği fikri ön plana çıkartılmıştır. Başka bir ifadeyle bir dile ait salt gramer bilgisinin dinî ve edebî metinleri çözümlemede eksik kalabileceğinin altı çizilerek Arap grameri özelinde bir değerlendirmeye gidilmiştir.

Konu ile ilgili ele alınan örneklerde daha çok klasik dönem dilci ve gramercilerin eserlerinden yararlanılmış gerekli görüldüğü yerlerde modern çalışmalara da atıfta bulunulmuştur. Destekleyici açıklamaların dilbilimsel ağırlıklı tefsirler üzerinden yapılmasına mümkün mertebe bağlı kalınmış az da olsa istişhâd bazında söylene gelen eski Arap şiirlerinden istifade edilmiştir.

Ülkemizde Arap gramerinin bu minvalde değerlendirilmeye tâbî tutulduğu araştırmalara daha fazla ihtiyaç duyulduğu düşünülerek ilgili çalışmanın yararlı olacağı ümit edilmektedir.

\footnotetext{
9 Mustafa Karagöz, Dilbilimsel Tefsir ve Kur'an'ı Anlamaya Katkısı: Hicri İlk Üç Asır (Kayseri: Erciyes Üniversitesi, Sosyal Bilimler Enstitüsü, Doktora Tezi, 2009), 118; Ali Temel, Dilbilimsel Tefsirlerde Kırâatlere Yaklaşım (Ankara: Ankara Üniversitesi, Sosyal Bilimler Enstitüsü, Doktora Tezi, 2015), 37.
} 


\section{Arap Dili Gramerini Dil-Toplum İlişkisi Üzerinden Okuma}

\section{1. Çevre Üzerinden Okuma}

Arap dili gramerinin gerek bir bilim dalı olarak isimlendirilmesi gerekse ihtiva ettiği konuların kavramsallaştırılarak öğrenilip öğretilmesi bakımından ortaya çıktığı çevreyle azımsanmayacak düzeyde bir ilişkisinin olduğu özellikle klasik dönemde yazılan eserlerde göze çarpmaktadır. İlmü'l-i'r'ab (علم الإعراب), İlmü'l-'Arabiyye (علم العربيّة) ve İlmü'n-nahv (علم النّدو) şeklindeki isimlendirmelerle biline gelen bu ilmin amaçlandığ hedefle bir şekilde bir irtibatının olduğu ilk bakışta zaten anlaşılabilmektedir. Fakat gramer ve yöre halkının dili arasındaki paralelliğe örnek olması bakımından Kemâleddin İbnü’l-Enbârî (öl. 577/1181) tarafından yapılan isimlendirme en dikkat çekenidir. İbnü'l-Enbârî, ictihâd mertebesine ulaşmanın yegâne yolunun ilgili diğer ilimlerde mahir olmakla birlikte gramer ilminin de etraflıca bilinmesine bağlı olduğunu aktardıktan sonra İslâm'ın ilk dönemlerinden itibaren söz konusu ilmin etrafında toplanılması hususundaki çağrılara bakıldığında bu ilime Edebiyat ilmi (علم الأدب) denilebileceğini savunur. “Etrafında bulunanları hazırladı̆̆ı sofraya çağıran kişinin nitelenmesinde kullanılan أدَبَ الرجلُ ifadesi bunu gerektirir." diyen İbnü'lEnbârî toplum nezdinde takdire şayan bir davranışın kavramsallaştııılmış halini asıl anlamının dışına çıkılmadan gramer ilmi için kullanılabileceğine işaret ederek isimlendirme düzeyinde bile gramer-toplum ilişkisine atıfta bulunmaya çalışmıştır. ${ }^{10}$

Gramer ilminde daha yumuşak bir çağrının yapılabilmesi amacıyla isimlerin son harflerinin düşürülmesi anlamında kullanılan terhîm (ترخيم) sözcügünü, dil ve edebiyat ustası olarak tanınan el-Asma'î̀'den (öl. 216/831) yardım alarak ${ }^{11}$ kavramsallaştıran Halil b. Ahmed el-Ferâhidî (ö. 175/791), Asma'î'nin toplumda ince ve yumuşak sese sahip kadınlar için kullanılan ${ }^{12}$ ifadesiyle temelde çelişmeyen bu kavramı gramere kazandırması da çevre ile doğrudan ilişkilendirilebilir.

Mütekellim yâ'sına izafe edilmiş bir kelimenin (أُمَّ gibi) sonunda bulunan esrenin ilk dönemlerde i’râb ya da binâ harekesi olarak görülüp görülmemesi hususunda net bir

\footnotetext{
10 Abdurrahmân b. Muhammed el-Enbârî İbnü'l-Enbârî, Lüma 'u'l-edille fî uṣûli'n-naḥv, thk. Said el-Afgânî (Suriye: Matba'atu'l-Câmi'ati's-Sûriye, 1377/1957), 95. Binâenaleyh ilk dönemlerde “edeb" sözcügünün şer'i ilimlerden ayrı olarak daha geniş, sosyal ve örfî bir içeriğe sahip olduğu söylenebilir. bk. Mehmet Şirin Çıkar, "Temel Kaynakları Bağlamında "İlmü'l-Edeb” Terimi ve İçeriği”, NÜSHA Şarkıyat Araştırmaları Dergisi, 5/19, (2005), 48.

11 Muhammed b. Mükerrem İbn Manzûr, Lisânü'l-Arab, (Kuveyt: Dârü'n-Nevâdir, 1431/2010), "rahame” 15/126.

12 İbrahim b. Ebi'l-Hasan Ali b. Ahmed el-Fehrî, Kenzü'l-küttâb, thk. Hayat Kâre (Birleşik Arap Emirlikleri: elMecma'u'l-'İlmî, 1425/2004), 1/296; Muhammed el-Murtazâ b. Muhammed b. Abdirrezzâk ez-Zebîdî, Tâcü'larûs min cevâhiri'l-Kāmûs, thk. Abdülkerim el-Azbâvî (Kuveyt: el-Meclisü'l-'İlmî li's-Sekâfe, 1421/2000), "rahame" , 32/238.
} 
yaklaşım yokken ${ }^{13}$ mebni olmasını gerektirecek bir neden olmadığı halde i'râb harekesini alamadığı ve bu açıdan الخصيّ şeklinde ifade edilip 'hadım etme eylemi'yle mukayese edildiğine rastlanılmaktadır. ${ }^{14}$ Ebü’l-Bekā el-Ukberî’ye (öl. 616/1219) göre bu tür kelimelerin sonunda bulunan esrenin binâ harekesi olarak değerlendirilmesi tartışmalıdır. Ayrıca iki خنتى مشكل karşıt harekeyi kabullenmesinden hareketle bu kelimelerin الخصيّ yerine (hermafrodit) kategorisinde yer alması daha uygundur. ${ }^{15}$

Burada mu'rab olduğu halde bazı durumlarda i'râb harekesi almayan ya da hem i'râb hem de binâ harekesine salahiyeti bulunduğu belirtilen bir kelimenin hadım edilmiş insan veya hayvanlara özgü olarak kullanılan bir kavramla isimlendirilmesinin yanı sıra hermafrodit olarak görülmesi dilbilimi bünyesinde kendine yer bulan bazı kavramların çevredeki somut şeylerden ilham alınarak nitelendirildiğini veya tanıtıldığını göstermektedir. ${ }^{16}$

Hemen hemen tüm klasik dönem gramer kitaplarında yer alan انت وأخو اتها رإنّ وأخو اتها أخوات , أمّهات الزّو ائد ,هذا وصواحبه , بنات الواو, بنات الياء ربنات الخمسة ربنات الأربعة ,أولاد الثلاثة ربنات الثلاثة ركان و أخو اتها الّّن gibi ifade tarzları, betimlemeler ve konu başlıklarında17 ise aile içi kavramların kullanıldığı görülmektedir. Aslında isim ve fiillerin gerek kök harflerinin belirtilmesinde gerekse sonlarında bulunan "vâv"(و) ve "ye" (ي) harflerinden dolayı isimlendirilmesinde kullanılan أولاد ifadelerinden kelimenin sahip olduğu harflerin sayısının kastedildiği

13 Osmân b. Cinnî el-Mevsılî, İbn Cinnî, el-Hูașâiș̣, thk. Muhammed Ali en-Necâr (Misır: el-Mektebetü'l-'İlmiyye, 1371/1952), 2/356; Hibetullah b. Alî b. Muhammed, İbnü'ş-Şecerî, Emâlî ibni'ş-Şecerî, thk. Muhammed etTannâhî (Kahire: Mektebetü'l-Hânecî, (1413/1992), 1/3-5; Abdullāh b. Ahmed el-Haşşâb, İbnü'l-Haşşâb, elMürtecel fí şerhi'l-cümel, thk. Ali Hayder (Dımaşk: Mektebetu Macma'i'l-Luga'1-Arabiyye, 1392/1972), 107-109.

14 Mansûr b. Felâh en-Nahvî, İbn Felâh, el-Muğnî fi'n- naḥv, thk. Abdurrezzâk Abdurrahman es-Sa'dî (Mekke: Ümmülkura Üniversitesi, 1404/1984), 2/176.

15 İbnü'ş-Şecerî, Emâlî ibni'ş-Şecerî, 1/3-5; İbnü'1-Haşşâb, el-Mürtecel, 107, 108; Abdullāh b. el-Hüseyn b. Abdillâh el-Ukberî, et-Tebyîn an mezâhibi'n-nahviyyîne'l-Bașriyyîn ve'l-Kûfiyyîn, thk. Abdurrahman el-Useymîn (Beyrut: Dâru'l-Garbi'l-İslâmî; 1416/1995), 150-152; Ukberî, Abdullāh b. el-Hüseyn b. Abdillâh. el-Mesâilü'l-hiilâfiyye fi'nnaḥv, thk. Abdulfettâh Selîm (Kahire: Mektebetü'l-Âdâb, 1428/2007), 67, 68.

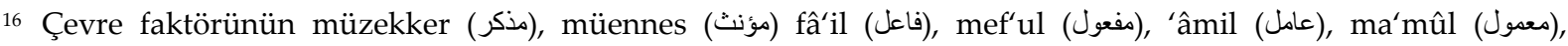

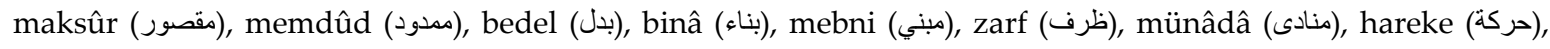

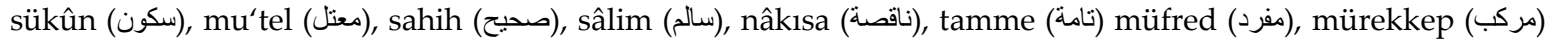
cemi' (جمع) gibi kavram ve kuramların üzerinde de etkili olduğu söylenebilir.

17 Amr b. Osmân b. Kanber Sîbeveyhi, el-Kitâb, thk. Abdüsselâm Muhammed Hârûn (Kahire: Mektebetu'lHânecî, 1408/1988), 2/80, 131, 338, 389, 392; 3/308, 340, 344, 433, 443, 447, 448, 528, 286; 4/46, 52, 78, 85, 245, 279, 286, 299, 303, 328, 386; Yahyâ b. Ziyâd el-Ferrâ', Meâni'l-Kurân, thk. M. Ali en-Neccâr-AhmedYûsuf Necâtî (Beyrut: 'Âlemu'l-Kutub, 1403/1983), 1/51, 2/328; Muhammed b. Yezîd el-Müberred, el-Mukteḍa, thk. Muhammed Abdülhâliḳ Uzayme (Kahire: 1415/1994), 1/204, 209; 2/105, 247; 4/88, 98; Muhammed b. es-Serî İbnü's-Serrâc, el-Uș̂ul fi'n-naḥv, thk. Abdülhüseyin el-Fetlî (Beyrut: Müessesetü'r-Risâle, 1417/1996), 2/323; 3/21, 42, 45, 52, 113, 149, 214, 221; Osmân b. Cinî el-Mevsılî, İbn Cinnî, el-Münșıf, thk. İ̉brâhim Mustafa-Abdullah Emîn (Kahire: Dâru İhyâi't-Turâsi'l-Arabî, 1373/1954), 1/35, 40, 45, 87, 153, 182; Muhammed b. Said, İbnü'1Müeddib, Dekâikü̈t-tașrîf, thk. Hatim Salih ed-Dâmin (Dımaşk: Dârü'l-Beşâir, 1425/2004), 419. 
bilinmektedir. Aynı şekilde bir fiil veya edâtın anlamlı bir cümle içindeki fonksiyonunun tespit edilmesinde kullanılan إنّ و أخواتها ,كان و أخوانها gibi başlıklardan, belirli bir işlevi gören birçok fiil veya edât arasında birinin ön plana çıkartılarak diğerlerinin ona benzetilmesi kastedilmiştir ki Arap toplumunda ilgili kelimelerin bu anlamda kullanıldığı örneklere sıklıkla rastlanılmaktadır. Örneğin benzeri tekrarlanmadığı için ölüm ve ölümün gerçekleştiği gece لهاه karşılaşan birine 19 لقي فلانٌ اخا الموتٍ cümlesi kullanılırken “Onunla ancak gizli bir şekilde

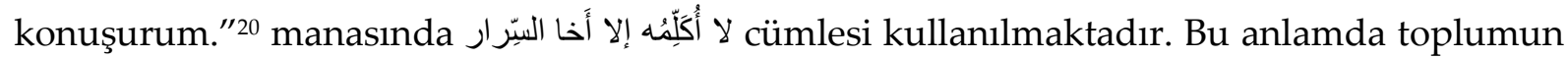
bir ferdi olan gramercilerin, bir fiil ve edâtla aynı işleve sahip olan diğer bazı fiil ve edâtları مثل kelimeleri yerine أخت veleriyle dile getirmeleri gramer ve dil-toplum

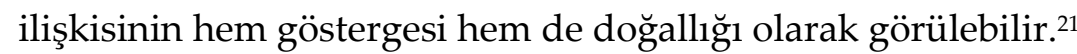

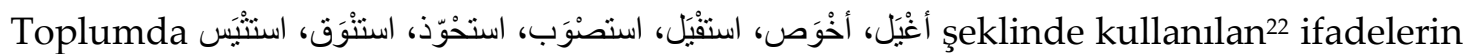

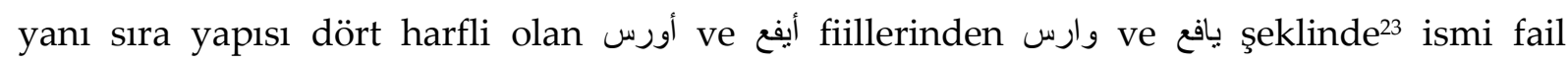
türetilmesi genel dil kurallarının dışına çıkıldığını göstermektedir. Halbuki bir fiilde harekeli olarak bulunan vâv ve yâ harflerinin elif harfine dönüşme zorunluluğu olduğu gibi yapısı dört harf ve üzeri fiillerin müzari kalıpları tespit edildikten sonra müzari olduğunu gösteren alametin yerine ötreli bir 'mim' harfinin getirilmesiyle ismi faillerinin elde edilebileceği yönündeki bilgiler tüm sarf kitaplarında genişçe yer almaktadır. شاذّ في القياس مطّردٌ في الاستعمال "Genel kurala muhalif ama kullanılışta yaygın." şeklinde başlıklandırılarak ele alınan bu söylem ve ifadeler sadece bir nahiv usul ilmi olarak da değerlendirilen ‘semâ' (السماع) ilkesiyle

18 Alî b. İsmâîl, İbn Sîde, el-Muḥkem ve'l-muhîtü̈l-aẓam, thk. Abdülhamit Hendâvî (Beyrut: Dâru'l-Kutubi'l'İlmiyye, 1421/2000),5/ 314; İbn Manzûr, Lisânü'l-Arab, 18/ 24; Abdurrahmân b. Ebî Bekr es-Süyûtî, el-Müzhir fî ulûmi'l-luğa ve envâ'ihâ (Kahire: Mektebetü'd-Dâri't-Turâs 2008, 2/263; Muhammed Edîb Abdülvâhit, elMu'cem fi'l-esâlîbi'l-İslâmiyye ve'l-'Arabiyye (Riyad: Mektebetü'l-'Abîkân, 1420/1999), 274.

19 Ahmed b. Muhammed b. Alî el-Feyyûmî, Kâmûsu'l-misbâhi'l-münîr fî̀ garîbi'ş-şerhi'l-kebîr li'r-Râfî̂ (Beyrut: Dâru'l-Fikr li't-Tabbâ' ve'n-Neşr, 1435/2014), 11.

20 Zebîdî, Tâcü'l-arûs min cevâhiri'l-Kāmûs, 37/50.

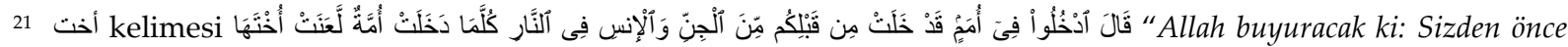
geçmiş cin ve insan toplulukları arasında siz de ateşe girin! Her ümmet girdikçe yoldaşlarına lânet edecektir. (Kur'an Yolu (Erişim 22 Nisan 2020), el-A'râf, 7/38) mealindeki âyette de benzerlik anlamında kullanılmıştır. bk. Ferra, Meâni'l-Ḳurân, 1/378; Muhammed b. Yûsuf b. Hayyân Ebû Hayyân, el-Baḥü̈l-muhị̂t, thk. Adil Ahmed Abdülmevcut-Ali Muhammed Muavvid (Beyrut: Dâru'l-Kutubi'l-'İlmiyye, 1413/1993), 4/298. Buna göre âyetten cehenneme girenlerin kendileriyle aynı batıl dine mensubiyeti bulunan diğer gruplara lanet edecekleri anlaşılmaktadır.

22 İbn Cinnî, el-Hașâiș, 1/98; Süyûtî, el-Müzhir fî̀ ulûmi'l-lug்a, 1/228.

23 İbnü'l-Müeddib, Dekâiküu't-tașrîf, 349. 
açılanabilir. ${ }^{24}$ Toplum tarafından benimsenen ve kullanıla gelen bu gibi ifade tarzları ve söylemlerin yazılı ve sözlü dil arasında mutlak manada bir uyumdan söz edilemeyeceğini de göstermektedir.

\subsection{Lehçeler Üzerinden Okuma}

Dilci ve gramerciler tarafından Arap dil kurallarının tespit edilmesi sürecinde dikkate değer görülen lehçelerin hangileri olduğu yönünde sorulan bir soruya cevap olabilecek açılamalar gramer ve dil-toplum ilişkisini doğrudan göstermesi açısından önem arz etmektedir. Bu yüzden yazılı bir şekilde günümüze kadar ulaşan ve daha sonra yazılmış olan eserlerin de temel kaynağını teşkil eden Sîbeveyhi'nin (öl. 180/796) el-Kitâb adlı eseri üzerinden birtakım değerlendirmelerin yapılması doğru bir adım olacaktır.

Sîbeveyhi'nin eserine bakıldığında birtakım kelimelerin gerek ses, gerek etimolojik gerekse sentaks boyutunun işlendiği sırada başta Tamim, Esed, Hicaz ${ }^{25}$ kabilelerinin lehçesi olmak üzere Mekke halkı, Medine halkı, Bekr, Kays, Tayi', Benî Adîy, Benî Süleym, Benî Sa'd, Fezare gibi birçok yöre halkı ve kabileden söz edildiği görülmektedir. ${ }^{26}$ Öte yandan eserde سمِعنا مَنْ يقولُ "A̧öyle diyen birilerinden işittik.", في كلام العرب "Arapların konuşmalarında.", أنّهم يقولون “Onlar derler ki.", قومٌ من العرب ثُرضى عربيّتهَ "Arapçalarına güvenilen bir kavim.”, ناساً من العرب “Araplardan bazılar1.", وسمعنا العربَ الموثوقَ بهم "Güvenilir baz1 Araplardan duyduk.", şeklinde belirsiz isnatlara da sıklıkla rastlanılmaktadı2²7 ki tüm bunlar onun dil kurallarının dayanakları ve ölçütlerini belli bir lehçe ve kabile diliyle sınırlandırmadığını göstermektedir. Kıraatler hususunda da normatif bir tavır takınmayan müellif, âyetlerin farklı kıraatlerini kendi aktardığ 1 kurallarla paralellik arz etmemesinden dolayı yanlış okuma tarzı olarak nitelemeyip aksine bunları Arap dilinin ayrı bir zenginliği olarak görmüştür. ${ }^{28}$

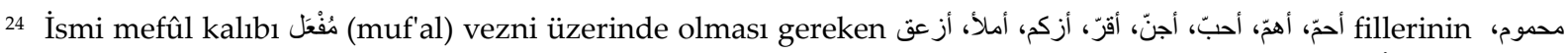
ş sهوم، محبوب، مجنون، مقرور ، مزكوم، مملوء ، مزعوق Hașâiș, 2/216.

25 Sîbeveyhi, el-Kitâb, 1/57, 59, 122, 126, 146, 224, 319, 321, 329, 343, 373, 374, 385, 388; 2/ 149, 276, 316, 319, 321, $413 ; 3 / 26,86,247,248,387,526,530,532,542,550,559 ; 4 / 107,108,110,111,121,125,158,170,177,182,199,211$, $220,256,417,418,457,473$.

26 Sîbeveyhi, el-Kitâb, 2/57; 4/181, 444. Sîbeveyhi'nin eserinde yer alan tüm kabilelerin listesi için Abdüsselâm Muhammed Hârûn tarafından tahkik edilen eserin 5. cildinin 195-202 sayfalarına bakılabilir.

27 Sîbeveyhi, el-Kitâb, 1/111, 122, 159, 182, 225, 396; 2/27, 83, 136, 139, 185, 192.

28 Mehmet Şirin Çıkar, Kıyas Bir Nahiv Usûl İlmi Kaynă̆ı (Van: Ahenk Yayınları, 2007), 51.
} 
Eser, yukarıda belirtilen özellikleriyle birlikte dil kurallarının dayanakları olarak dört yüze yakın âyet ${ }^{29}$ ve iki yüz otuzu aşkın şairden yaklaşık bin elli beyti ihtiva etmesi ${ }^{30}$, İslâmî dönemle birlikte Câhiliye dönemi şairlerine defalarca atıfta bulunmas1 ${ }^{31}$ ayrıca harflerin seslerini ve mahreçlerini titizlikle incelemesi yönüyle bir nevi gramer, edebiyat ve lügatın bir arada işlendiği ilk kitaptır ve daha sonra kaleme alınan gramer kitaplarından bu yönüyle ayrılmaktadır. Kimi edipler tarafından Batlamyus'un Almagest'i ve Aristo'nun Organon'uyla bir arada zikredilmesi, ${ }^{32}$ kimi müfessirlerce de tefsir ilminin ön koşulu sayılacak kadar değer atfedilmesinin ${ }^{33}$ nedeni, sadece nahiv ve sarf kuralların ihtiva etmesinden kaynaklı olmasa gerektir. Nitekim dil ile ilgili teorik bilgilerin yetersizliğine dikkat çeken ünlü sosyolog İbn Haldûn (öl. 808/1406), “Sîbeveyhi'nin kitabı dil kurallarıyla birlikte Arapların ifade tarzları, şiirleri ve deyimleriyle doludur." 34 diyerek buna açıkça işaret etmiştir.

Lehçe faktörünün gramer kuralları üzerindeki bariz bir rolü لغة أكلوني البراغيث şeklinde adlandırılan ${ }^{35}$ okuyuş tarzında da görülmektedir. Zira bir cümlede zâhir isim olması kaydıyla fâilin tekil, ikil veya çoğul olarak bulunması fiilin sadece tekil bir şekilde ifade ضرباني أخو اك ,ضربوني قومك وقد يُقالُ سعِدا وسعِدو / gibi ifadelerin tümüyle reddedilmediği görülmektedir. سعِدوا لve سعِدا (gibi zamirli bir şekilde telaffuz edildiği halde) zahir bir isme isnadı (da) olabilir. diyerek nadirde olsa bu tür kullanışların var olabileceğini belirtir. ${ }^{37}$ Ebû Hayyân el-Endelûsî de (öl. 745/1344) bu tür ifade biçimlerini zayıf ve kayda değer görmeyen gramercilere وكَثُةُ وُرودُ ذلك يدلّ على أنّها ليستْ ضعيفة Bu (gibi) ifadelerin (toplumda) çok fazla yer alması/kullanılması zayıf olmadığını göstermektedir." şeklinde cevap vererek onlarla hemfikir olmadığını beyan eder. ${ }^{38}$

29 Emânuddîn Hathât, el-İstidlâlu'n- nahvố fî Kitâb Sîbeveyhi ( Suriye: Câmi'atu'1-Haleb, 1414/1993), 125.

30 Ahmed et-Tantâvî, Neş'etü'n-naḥv ve târîhu eşheri'n-nuhât (Mısır: Dârü'l-Ma'ârif, 1995), 86, 87.

${ }^{31}$ Georges Terabichi, Nakd-u nakdi'l-akli'l-'Arabî (Beyrut: Dâru's-Sâkî, 1998), 182, 183.

32 Yâkūt b. Abdillâh el-Hamevî, Mu'cemü'l-üdebâ, thk. İhsan Abbas (Beyrut: Dârü'l-Garbi'l-İslâmî, 1993), 5/2124

33 Muhammed b. Ahmed b. Ebî Bekr el-Kurtubî, el-Câmi li-ậkâmi'l-Kurân, thk. Abdullah b. Abdulmuhsin etTürkî (Beyrut: Müessesetü'r-Risâle, 1427/2006), 1/39; Ebû Hayyân, el-Bahrü'l-muhîț, 1/101.

34 Abdurrahmân b. Muhammed İbn Haldûn, Mukaddimetu ibn Haldûn, thk. Abdullah Muhammed ed-Dervîş (Dımaşk: Dârü'l-Belhî, 1425/2004), 2/385, 386.

35 Şihâbüddîn Ahmed b. Muhammed el-Hafâcî, Şerḥu Dürreti'l-g்avvâs, thk. Abdulhafiz Ferağlî-Ali el-Karnî (Beyrut: Dâru'l-Cîl, 1417/1996), 415; Hasan ‘Avn, el-Lügatu ve'n-naḥv (b.y. Câmi 'atü'l-İskenderiye, 1952$), 59$.

36 Sîbeveyhi, el-Kitâb, 2/40, 41; İbnü's-Serrâc, el-Uș̂̂l, 1/70, 71.

37 Muhammed b. Abdillâh b. Mâlik İbn Mâlik, Elfiyyetu İbn Mâlik, thk. Süleyman b. Abdülaziz el-`Uyûnî (Riyad: Mektebetu Dâri'l-Minhâc, 1428/2007), 99.

38 Muhammed b. Yûsuf b. Hayyân Ebû Hayyân, İrtişâfü'ḍ-ḍarab min lisâni'l- Arab, thk. Recep Osman MuhammedRamazan Abdüttevvab (Kahire: Mektebetü'l-Hânecî, 1418/1998), 2/739. 
Tesniye alâmeti aldığı halde zahir isme de isnad edilen fiile örnek, Ubeydullāh b.

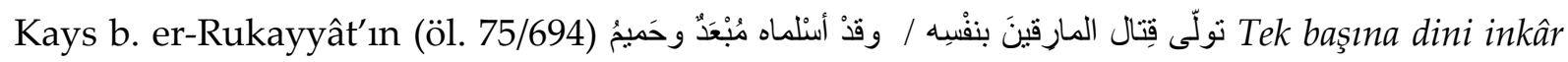
edenlere göğ̈̈̈s gerdi (ama gerek) tanımayanı (gerekse) tanıyanı onu teslim ettiler/yüzüstü bıraktılar. ${ }^{39}$ beyti; gaib müenneslerin çoğul alâmetine ise Ferezdak olarak tanınan Hemmâm b. Gâlib'in

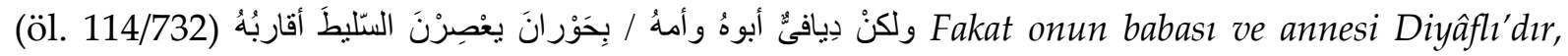
akrabaları (da) Havran'da (zeytinin) yă̆ını sıkıyorlar. ${ }^{40}$ beyti delil gösterilmiştir. ${ }^{41}$

Bazen insaftan uzak eleştiriler de Arap toplumu ve konuştukları lehçelerden bi haber olmakla ilişkilendirilebilir. Örneğin İmam Azam Ebû Hanîfe'nin (öl. 150/767) meşhur Ebûkubeys dağının adını بأبا قُبيس şeklinde telaffuz ettiği aktarılmaktadır.42 Buna göre بأبي قبيس harfi, cer amelini işlediği için doğru telaffuzun "ب " şeklinde olması gerekir. Oysa Araplar arasında اب kelimesinin hem ref' hem nasb hem de cer durumunda sadece "elif" ile telaffuz eden kesimlerin bulunduğu yönündeki rivayetler ve gramer kitaplarındaki açıklamalar bu eleştirinin ya kasıtlı yapıldığını ya da mübalağa içerdiğini göstermektedir. Ünlü dilci ve gramerci İbn Mâlik (öl. 672/1274) أخم ve أب kelimelerini kastederek وقصنرُها مِنْ نَقِسهنْ اشهرُ Bu kelimelerin kasr (ref', nasb ve cer durumlarmda sonlarında elif harfinin bulunması) durumu naks (hareke ile irâb edilmelerinden) daha yaygındır. diyerek bu yaklaşıma açıklık getirir. ${ }^{43}$ Daha çok tarihçi kimliğiyle tanınan Salâhuddîn esSafedî (öl. 764/1363) de bu eleştiriye karşı çıkmakta ve إنّ أباها وأبا أباها / قد بلغا في المجد غا يناها Şüphesiz ki onun (Selma'nın) babası ve babasının babası cömertliğin her iki zirvesine ulaşmışlardır. anlamındaki beyti delil gösterip Ebû Hanife'ye karşı yapılan eleştiriyi anlamsız bulmaktadır. ${ }^{44}$ Çünkü beyitte yer alan üçüncü أب kelimesi muzafun ileyh olduğu halde "yâ" harfi ile değil "elif” ile kullanılmıştır. Başka bir ifadeyle beytin ilk dizesi إنّ أباها وأبا أبيها şeklinde biline gelen kuralla söylenmemiştir. ${ }^{45}$ Bundan dolayı kelimelerin gramer boyutu ve işlevleriyle beraber yöresel çevre ve dil ile bağının olup olmadığı yönündeki bir bilgi,

39 Abdullāh b. Yûsuf b. Hişâm İbn Hişâm, Şerḥu Şüzûri'ż-Žeheb, thk. Muhammed Ebu'l-Fazl 'Aşûr (Beyrut: Dâru İhyâi't-Turâsi'l-'Arabî, 1422/2001), 96; Abdullah b. Abdirrahmân b. Akīl İbn Âkîl, Şerḥu İbn 'Akīl 'alâ Elfiyyeti İbn Mâlik, thk. Muhammed Muhyiddin Abdülhamît (Kahire: Dâru't-Turâs, 1400/1980), 2/81.

40 Sîbeveyhi, el-Kitâb, 2/40.

41 İlk beyitte أسلم fiili ikil alâmetiyle birliktelik ettiği halde sonrasında yer alan ميح velimelerine isnad edilmiştir. İkinci beyitte يعصر fiili gaib müenneslerin çoğul alâmetiyle birliktelik ettiği halde sonrasında bulunan أقاربه kelimesine isnad edilmiştir.

42 Ahmed b. Muhammed İbn Abdürabbih, el-ịkndül-ferîd, thk. Mufîd Muhammed Kamîha (Beyrut: Dâru'lKutubi'l-'Illmiyye, 1404/1983), 2/310, 311.

43 İbn Mâlik, Elfiyyetu İbn Mâlik, 73.

44 Halîl b. İzziddîn Aybeg b. Abdillâh es-Safedî, el-Vâfî bi'l-vefeyât, thk. Ahmed el-Arnavut-Mustafa Türkî (Beyrut: Dâruİhyâi't-Turâsi'l-'Arabî, , 1420/2000), $27 / 92$.

45 Abdurrahmân b. Ebî Bekr es-Süyûtî, el-Behcetü'l-merżıyye, thk. Ali es-Seyyâh (Dâru'l-'ulûm, 1433/2012), 1/42, 43. 
tutarsız eleştirilerin önünü kesebileceği gibi daha sağlıklı sonuçların ortaya çıkmasına da yardımcı olacaktır.

Yukarıdaki örnek ve etrafında cereyan eden değerlendirmeler perspektifinde Yahyâ b. Ziyâd el-Ferrâ (öl. 207/822) ve Muhammed b. Yezîd el-Müberred (öl. 286/900) tarafından nakledilen rivayetlerde de lehçe faktörünün rolü görülmektedir. Ferrâ, tesniyenin üç durumda (ref', nasb, cer) elif ile irâb edildiğini belirtirken Harisoğulları lehçesini dayanak göstermekte; ${ }^{46}$ Müberred de رضي الله عليك şeklinde bir ifade tarzını Amiroğulları lehçesiyle irtibatlandırmaktadır. ${ }^{47}$ Benzer bir yaklaşım "Yukarılardan geldim." anlamına gelen

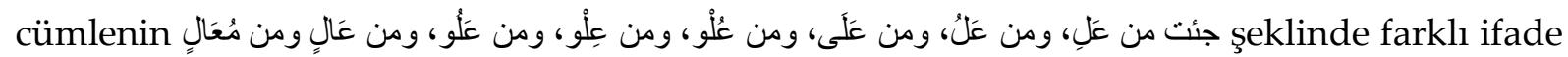
tarzlarıyla söylendiğini aktaran ${ }^{48}$ Celâlüddîn es-Suyûtî (öl. 911/1505) tarafından da sergilenmiş ve söz konusu ifade tarzlarının kullanılabilir olduğuna özellikle vurgu yapılmıştır. Öte yandan hareke değişikliği açısından bazı mazi fiillerinin farklı müzari yapılarına sahip olmaları Araplar tarafından kullanılan iki ayrı lehçeye dayandırılarak açıklanmaya çalışılmıştır. Bazen iki lehçenin iç içe geçmesi (التداخل) ş̧eklinde de değerlendirilen bu durumun lehçe farklılığı olarak değerlendirilmesi gerektiği ifade edilmiş ve yanlış addedilmesine karşı çıkılmıştır. ${ }^{49}$ Arap toplumu ve sahip oldukları lehçeler arasında herhangi bir fark olmadığını söyleyen gramercilerin yaklaşımlar1 ${ }^{50}$ da bunu teyit etmektedir ki tüm bu görüş ve açılamalar lehçe farklılıklarının olağan ve kabul edilebilir olduğunu göstermektedir.

Elbette ki bazı lehçelerin daha fasih sayıldığı doğrudur. Örneğin Hicaz bölgesinde bulunan kabilelerin lehçeleri arasında Kur'ân diline daha yakın olması münasebetiyle Kureyş lehçesi daha fasih sayılırken Necid lehçeleri arasında da Temîm lehçesi örnek lehçe kabul edilmiştir. ${ }^{11}$ Kays ve Esed kabilelerinin lehçelerinden yapılan alıntıların çok daha fazla

46 Ferrâ, Ma'âni'l- Kurân, 2/184. Kinâne lehçesinde de cümledeki konumu fark etmeksizin tesniyenin sürekli olarak elif harfi ile telaffuz edildiği kaydedilmiştir. bk. Emin Cengiz, Endülüs Tefsirinde Filolojik Yaklaşımlar İbn Ebî Zemenin Örneği, ed. İbrahim Baz, Yaşar Acat (Mardin: Şırnak Üniversitesi Yayınları, 2018), 177.

47 Muhammed b. Yezîd el-Müberred, el-Kâmil, thk. Muhammed Ahmeded-Dâlî (Beyrut: Müessesetü'r-Risâle, 1412/1992), 2/722.

48 Süyûtî, el-Müzhir fî̀ ulûmi'l-lugga, 1/263.

49 Abdullah b. Ca'fer b. Dürüsteveyh İbn Dürüsteveyh, Tașhîhu'l-fașîh, thk. Muhammed Bedevî el-MahtûnRamazan Abdüttevvâb (Kahire: by.1425/2004), 37, 38; Süyûtî, el-Müzhir fî ulûmi'l-lugga, 1/263, 264.

50 Abdurrahmân b. İshâk ez-Zeccâcî, el-Îżâh fị ileli'n-naḥv, thk. Mâzin el-Mübârek (Beyrut: Dâru'n-Nefâis,

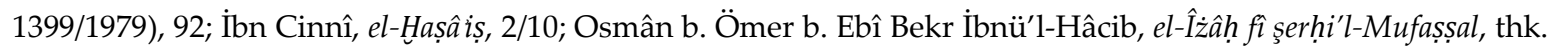
Mûsâ Binây el-Alîlî (Bağdad: Matba'atü'l-'Anî, 1402/1982), 1/359.

51 Yonis İnanç, “Nahiv İlmi Açısından Temîm Lehçesinin İstişhâd Değeri”, Sakarya Üniversitesi İlahiyat Fakültesi Dergisi 17/31 (Haziran 2015), 2. 
olduğu da bilinmektedir. ${ }^{52}$ Ama bu durumun bazı lehçelerin dikkate alınıp bazılarının dikkate alınmadığı şeklinde yorumlanması hassaten Kur'ân'ı Kerîm açısından çok da doğru olmayabilir..$^{53}$ Belki de söz konusu duruma, dînî veya sosyal nedenlerle belli lehçelerin diğer lehçelere ait bir takım özellikleri alarak gelişmesi ve zamanla ortak dil hâline gelmesi şeklinde bir açıklamanın getirilmesi daha sahici ve ikna edici olacaktır.

\subsection{Ayet Yorumları ve Bireysel Değerlendirmeler Üzerinden Okuma}

Bir ilim dalında söz sahibi olabilecek kadar ilmi birikime sahip olunduktan sonra ayrıca belli bir konu hakkında ortaya atılan görüşlerin reddedilmemesi koşuluyla sergilenen kişisel yaklaşım ve mülahazaların kabul görebileceği büyük bir olasılıktır. Bu yüzden gramer ve dil-toplum ilişkisinin boyutunu göstermesi açısından yapılmış olan birtakım bireysel açıklama ve tahlillerin aktarılması yararlı olacaktır. Kur'ân'ı Kerîm üzerinden yapılan açıklamaları ele alırsak Hz. Ömer (öl. 23/644) ve İbn Abbas'a (öl. 68/687-88) nispet edilen اؤ يأخذَهم على açılamalar önem arz etmektedir. Muhammed b. Ahmed el-Kurtubî (öl. 671/1273) “Veya onları korku (eksiklik) üzere iken yakalamayacağından emin midirler? Şüphesiz Rabbiniz çok esirgeyici ve çok merhametlidir. "54 mealindeki âyetin tefsiri esnasında şöyle bir rivayette bulunur: “Hz. Ömer (r.a.) minber üzerinde ilgili âyeti hazır bulunanlara sorduğunda Hüzeyloğullarından bir kişi kendisine نخوّف ifadesinin eksiklik ve noksanlık anlamına geldiğini söylemesi üzerine Hz. Ömer bu hususta Arapların şiirinden bir delil olup olmadığını sorar. Adam kendilerinden bir şâir olan Ebû Kebîr el-Hüzelî’nin Taşıdığı yük dişi devenin kalkık hörgücünü, zımparanın neb'a ă̆acını eksilttiği gibi eksiltti. anlamına gelen نخوّف Şiirinden söz eder.5 Bunun üzerine Hz. Ömer Kur'ân'ı anlama noktasında eski Arap şiirlerinden de yararlanılması gerektiği yönünde bir talimat verir."56 İbn Abbâs'a ise "Bana Kur'ân'ın garibini (çok fazla anlaşılır olmayanını) sorduğunuzda bunu (bir de) şiirde arayın, çünkü şiir Arapların divanıdır." manasına gelen ifadesi nispet edilmektedir.57 Buna göre

52 Çıkar, Kıyas Bir Nahiv Usûl İlmi Kaynă̆ı, 58.

53 Hasan 'Avn, el-Lügatu ve'n-nahv, 76.

54 Kur'an Yolu (Erișim 4 Nisan 2020), en-Nahl 16/47.

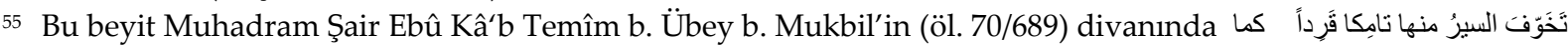

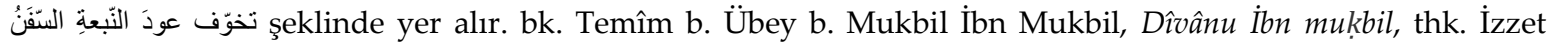
Hasan (Beyrut: Dârü'ş-şarki'l-Arabî, 1416/1995), 283.

56 Kurtubî, el-Câm' li ahkâmi'l-Kur'ân, 12/332.

57 Muhammed b. el-Kāsım el-Enbârî İbnü'l-Enbârî, Kitâbü İżâhi'l-vakf ve'l-ibtidâ' fî Kitâbillâh, thk. Muhyiddîn Abdurrahman Ramazan (Dımaşk: Matbûât Mecmai'l-Lugati'l-Arabiyye, 1391/1971), 1/62; Ahmed b. Yahyâ eşŞeybânî Sa'leb, Mecâlisu Sa'leb, thk. Abdüsselam Muhammed Harûn (Mısır: Dâru'l-Ma'ârif, 1960), 1/ 317. 
gerek Hz. Ömer gerekse İbn Abbas'ın estetik bir sanat olan şiirin ritim, ses, ahenk ve biçimi dışında ihtiva ettiği kelimelerin anlam çerçevesinin bilinmesinin önemine vurgu yapmaya çalıştıkları söylenebilir. Zira İbn Reşîk el-Kayrevânî'nin de (öl. 456/1064) dediği gibi şiir, hayali bir şey olmayıp Arap toplumu tarafından öteden beri nazım dışında söylenmiş olan tüm duygu, ifade ve açıklamaların kafiyeli tekrarından başka bir şey değildir. ${ }^{58}$

Kur'ân-1 Kerîm perspektifinde bir değerlendirme Basra ekolünün en önemli

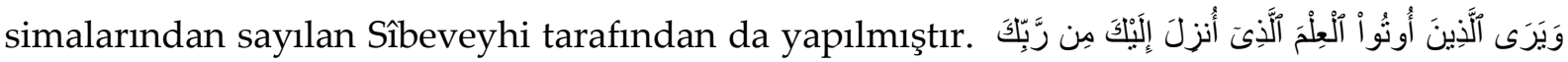
“'Kendilerine ilim verilenler (âlimler), Rabbinden sana indirilenin hak/gerçek olduğunu

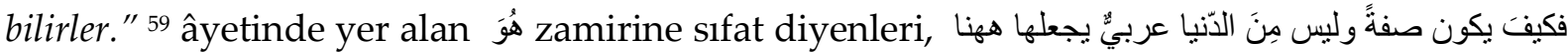
"Hiçbir Arap tarafından zahir isme sıfat yapılmayan bu (sözcük) nasıl sıfat olabilir ki?"60 diyerek eleştiren Sîbeveyhi gramatik tahlillerin genel dilin ifade tarzlarına tezatlık durumunu kabul etmediğini açıkça belirtir. ${ }^{61}$

Hicri dördüncü yüz yıl edebiyatçılarından olan Ebû Zeyd el-Kureşî, “Ufak tefek kusurlar hariç, büyük günahlardan ve çirkin işlerden kaçınanlar."62 şeklinde meal verilen الّّذين

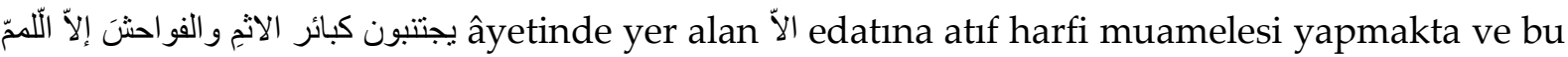
edatının atıf harfi olan "vâv" gibi değerlendirilmesi gerektiğini ileri sürmektedir.63 Dolayısıyla ona göre âyete "Büyük günahlar, çirkin işler ve ufak sayılacak hatalardan sakınanlar." وكلُ أخٍ beytini delil gösteren Kureşî́ye göre beyite Kardeşinin ömrüne yeminim olsun ferkadân (olarak adlandırılan) yıldızlar hariç her kardeş (mutlaka) kardeşinden ayrılacaktır. şeklinde bir mananın verilmesi doğru değildir. ${ }^{64}$ Aslında gerek klasik sözlüklerde إلإ nın vâv (و) manasında gelebileceği yönündeki bilgiler, ${ }^{65}$ gerekse beytin öncesinde yer alan dizelerin yaşlılıktan sızlanma ve birbirlerine yakın olan her şeyin zamanla birbirlerinden

58 Hasen b. Reşîk el-Kayrevânî İbn Reşîk, el-Umde fî̀ mehâsini'ş-şir ve âdâbih ve naḳdih, thk. Muhammed Muhyiddin Abdulhamid (Suriye: Dâru'l-Cîl, 1401/1981), 1/20.

59 Kur'an Yolu (Erişim 4 Nisan 2020), Sebe' 34/6.

60 Sîbeveyhi, el-Kitâb, 2/390.

61 Sîbeveyhi أعطى gibi iki mef'ûl isteyen bir fiilin, أعطاك إيّاي veya gibi ikinci mef'ûlünün munfasıl olmas1 koşuluyla ilk mef' ûlünün birinci şahıslara ait zamirden oluşma zorunluluğunun bulunmadığını söyler. Her iki mef' ûlün muttasıl zamir olması durumunda ise önce birinci şahıs zamirinin kullanılmasının gerekliliğine

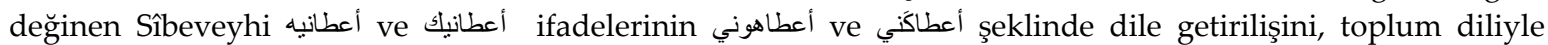
tezatlık oluşturduğu gerekçesiyle reddeder. bk. Sîbeveyhi, el-Kitâb, 2/363, 364.

62 Kur'an Yolu (Erişim 7 Nisan 2020), en-Necm 53/32.

63 Ebû Zeyd el-Kureşî, Cemheretueş'âri'l-Arab, thk. Ali Muhammed el-Becâvî (Kahire: Dâru Nahdeti Misır, 1981), $11,12$.

${ }^{64}$ Kureşî, Cemheretu eş'âri'l-Arab, 13, 14.

65 İsmâîl b. Hammâd el-Cevherî, Tâcü'l-lugga ve șıhâhụ'l-Arabiyye, thk. Ahmed Abdülgafur Attâr (Beyrut: Dâru'l'İlmli'l-Melâyîn, 1399/1979), 6/2545. 
uzaklaşacağına değinmesi ${ }^{66}$ Kureşî tarafından verilen mananın da dikkate alınması gerektiğini göstermektedir.

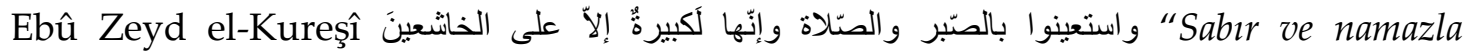
Allah'tan yardım isteyin. Şüphesiz bunlar, Allah'a huşû ile boyun eğenlerden başkasına ağır gelir."67 mealindeki âyette de إن harfine bitişmiş olan هamirinin, tesniye olmamasına rağmen hem kelimelerine döndüğünü belirtir. Öte yandan üst üste söylenen iki özneden sonra bir tek yüklemin getirilmesi her iki öznenin o yüklemle irtibatlandırılabileceğini ifade eden Kureşî نحنُ بما عندناو أنتَ بما / عندلكَ راضٍ و الرأَى مُختلف beytinin bu duruma delil olabileceğini söyler. Çünkü beyitte نحن ve أنت öznelerinden sonra راض şeklinde bir tek yüklemin yer alması beytin نحنُ بِما عندنار راضونَ Biz yanımızdaki şeylerden memnunuz, و و Sen (de) yanındaki şeyden memnunsun. şeklinde yorumlanmasını gerektirir. ${ }^{68}$

Aktarılan bilgiler göz önünde bulundurulduğunda آلَقِيا في جهنّمَ كلَّ كفّارٍ عنيدٍ âyetinde69 yer alan الَّقِيا fiiline "İkiniz atınız." şeklinde bir anlamın verilmesi salt gramer kurallarına göre doğrudur. Ama tesniye kipiyle müfred bir şahsa hitap edilebileceği yönündeki bir bilgi de ilgili âyetin yorumlanmasında göz önünde bulundurulabilir. İbn Fâris (öl. 395/1004) باب أمر “Tesniye lafzıyla müfred (şahsa) emir yapılabileceği (yönündeki) bâb.” başlığı altında Arapların افعلا ذالك ifadesini tekil olarak kullandığını aktardıktan sonra aynı durum için فإنْ تَزْجُر اني يا ابن عفانَ أنزجر / Ey Affân oğlu eğger beni azarlarsan ben de seni azarlarım; (beni) terk edersen (elbette ki) korunması gereken şerefimi korurum. beytini delil olarak sunar. ${ }^{70}$ Fahreddin er-Râzî (öl. 606/1210) de “Müfred emir kipinin tesniye kipiyle dile getirilmesi Arapların âdetidir." der. ${ }^{71}$ Bu açıdan Yüce Allah tarafından Arap toplumuna gönderilmiş olan sözlü mesajların gramatik, etimolojik ve semantik açıdan onların günlük konuşmaları ve ifade tarzlarıyla örtüşme olasılığının göz önünde bulundurulması

${ }^{66}$ Hasen b. Bişr el-Âmidî, el-Mü telifve'l-muhtelif, thk. Fritz Krenkow (Beyrut: Dârü'1-Cîl, 1411/1991), 106.

${ }^{67}$ Kur'an Yolu (Erişim 7 Nisan 2020), el-Bakara 2/45.

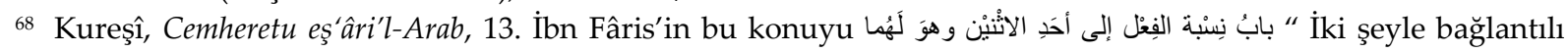
olan fiilin (onlardan) sadece birine nispet edilmesi yönündeki bâb." şeklinde bir başlıkla ele aldı̆̆ı görülmektedir. bk. Ahmed b. Fâris b. Zekeriyyâ İbn Fâris, eș-Ṣâhịib̂ fî fiḳhi'l-lugga. thk. Ömer Faruk et-Tabbâ' (Beyrut: Mektebetü'l-Ma'ârif, 1414/1993), 222.

69 Kur'an Yolu (Erişim 1 Nisan 2020), Kâf 50/24.

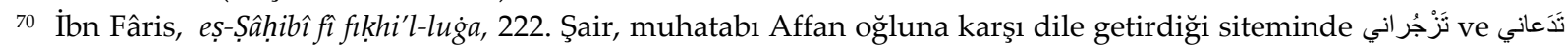
fiillerini tesniye olarak kullanmıştır.

${ }^{71}$ Muhammed b. Ömer er-Râzî, Mefâtîhu'l-ġayb (Beyrut: Dâru'l-Fikr, 1401/1981), 28/165. 
önemlidir.72 Hatta kelimelerin yansıttığı anlamlarda zamanla birtakım değişimlerin kaçınılmaz olduğ $\mathrm{u}^{73}$ düşünülürse zorunludur.

$\mathrm{Bu}$ konuda önemli açılamalarda bulunan âlimlerden birisi de Arap dili ve tefsir âlimi Ebû Zekeriyyâ Yahyâ b. Ziyâd el-Ferrâ'dır. O, Ma'âni'l-Kur'ân adlı eserinde قدُ كانَ لَكُمْ آيةٌ (Bedir'de) karşı karşıya gelen şu iki grupta sizin için (büyük) bir ibret vardır: Biri Allah yolunda çarpışan bir grup, diğeri ise gözleriyle

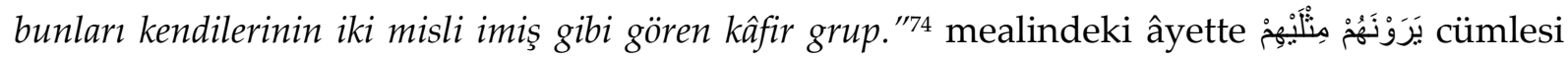
üzerinde durmakta, Allah yolunda savaşan grubun gören, diğer grubun ise görülen olduğu yönünde bir kanaate sahip olduğunu söyler. Müminlerin sayısı üç yüz küsur olduğuna

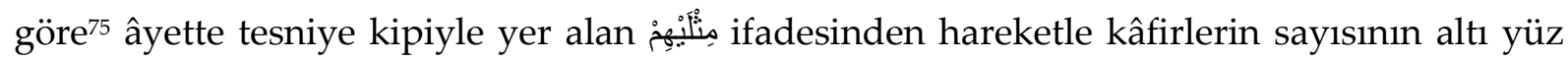
küsur olduğunu belirtenlerin görüşlerine mesafeli durmakta ve sayısı yaklaşık dokuz yüz elli olan kâfirlerin Müslümanlar tarafından eksiksiz bir şekilde görüldüğünü söylemektedir.

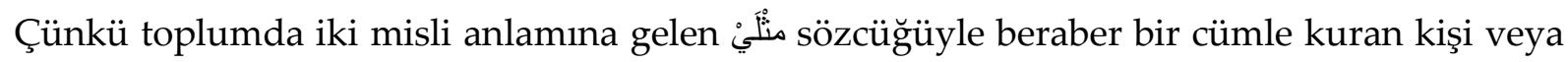

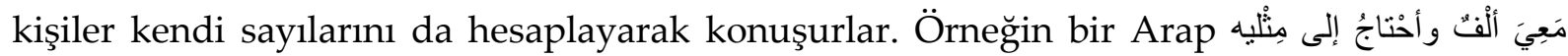
"Yanımda bin (dirhem-lira vs.) var ve iki misline de muhtacım." derse aslında üç bine ihtiyacı olduğunu anlatmaya çalışır. Ya da bir hizmetçi çalıştıran birisinin أحتناجُ إلىى مِتْلِه “Onun gibi birisine ihtiyacım var." demesi iki hizmetçiye; أحْتاجُ إلْى مِنْلَّْ عَبدي "Hizmetçimin (sayısının) iki katına ihtiyacım var." demesi halinde ise üç hizmetçiye ihtiyacının olduğunu söylemeye çalışmaktadır. ${ }^{76}$ Aslında Ferrâ'nın söylemeye çalıştığ1 şey şudur: “Bedir'de müminlerin sayısı üç yüz küsur olduğuna göre kâfirleri kendi sayılarının bir misli olarak görmeleri, kendi mevcut sayılarının da eklenmesi durumunda kâfirlerin sayısının altı yüz küsur; iki misli görmeleri halinde ise dokuz yüz küsur olduğunu göstermektedir."

72 Kur'ân'da yer alan bazı ifade tarzlarının Arap toplumunun günlük ağzıyla benzerlik taşıdığ1 yönünde Ebû Zeyd el-Kureşî’nin eserinde yer verdiği فى القرآن مثلُ ما فى كلام العرب "Kur'ân'da Arapların konuşmalarıyla benzerlik arz eden ifadeler." şeklindeki başlığın altında ilgili mevzuya bakılabilir. bk. Kureşî Cemheretu eş'âri'lArab, 12.

73 Zafer Önler, Dil ve Kültür Üzerine Yazılar (İstanbul: Dergâh Yayınları, 2019), 450, 451. Türkçeye örnek olarak Yunus Emre'nin Saçın Çözüp benim için yaşın yaşın ă̆lar mısın? dizesinde yer alan "yaşın" sözcüğünün günümüz Türkçesinde yer alan ve "1slak" anlamına gelen "yaş” sözcüğüyle bağdaştırılıp "1slak islak” şeklinde yorumlayanların yaklaşımı verilebilir. Zira bu yaklaşım eski Türkçede "yaşın” sözcügünün "gizlemekgizlenmek" anlamlarına geldiğini bilmemekten kaynaklanmaktadır. bk. Önler, Dil ve Kültür Üzerine Yazılar,

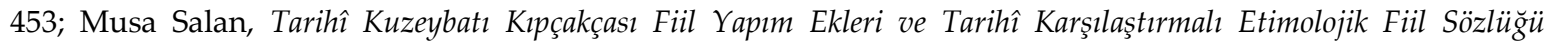
(İstanbul: Hiperlink Eğitim İletişim Yayıncılık, 2019), 564.

74 Kur'an Yolu (Erişim 10 Mayıs 2020), Âl-i İmrân 3/13.

75 İbrâhîm b. es-Serî b. Sehl ez- Zeccâc, Meâni'l-Kurân ve irâbüh, thk. Abdülcelil Abduh Şelebî (Beyrut: Âlemu'lKutub, 1408/1988), 1/382; Ebû Hayyân, el-Bahrü̈l-muhît, 2/411, 412

76 Ferrâ, Ma'âni'l- Kur ân, 1/194. 
İbn Cerîr et-Taberî (öl. 310/923) isim belirtmeden Ferrâ'nın ifadelerini olduğu gibi aktarır ve kâfirlerin Müslümanları kendilerinin iki katı gördükleri yönündeki yaklaşımlara da katılmadığını ifade der. ${ }^{77}$ Tefsir ve kıraat âlimi Mekkî b. Ebî Tâlib’in (öl. 437/1045) "Allah yolunda savaşan grup görendir, kâfir grup ise görülendir." şeklindeki açılaması da Ferrâ'nın görüşüyle örtüşmektedir.78

Ayrıca müfred, tesniye ve cemi kiplerinin birbirlerinin yerine kullanılması, soru cümlesinin ardından cevap cümlesine yer verilmemesi تلك ve ذلك ism-i işaretleri arasında bir ayrımın yapılmaması, ismi mefulün ismi fail kipi üzerinde gelmesi, birden fazla isimle ifade edilebilen kelimelerde müzekkerlik ve müenneslik olasılığının zamirlerin mercilerine yansıması, إِ edâtının belirli şartlarda atıf edâtı olan vâv (و) manasına kullanılması, belli cer harfleriyle meful alan bazı fiillerin zaman zaman müstakil olarak da kullanılması, belli şartlarda edât edâtının مع edibi değerlendirilmesi, nehiy kipiyle dile getirilen bazı ifadelerin aslı itibariyle bir yasaklama olmadığı, emir kipinin serbestliği karşıladığı̆, أو

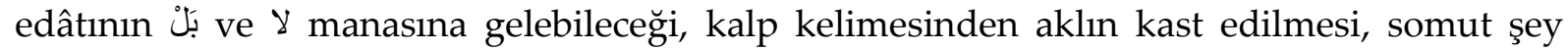
karşılığında kullanılan bir kelimenin asıl manasının dışına çıkılmadan soyut olarak da kullanılabilmesi, özel bir hitabın genelmiş gibi ifade edilmesi, olumsuzluk edâtı olan $\vee$ kelimesinin menfi cümlelerde zait addedilmesi, asıl itibariyle cezim yapmayan إذا edâtının cezim yapması, bazı fiillerin telaffuzlarında görünen hareke değişikliği, sıyak ve sıbak gözetilerek cer harflerinin birbirlerinin yerine kullanılabileceği, أر ve fiillerinden sonra sebebiyet bildiren lâm (ل) أن أن manasının verilmesi gibi üslûp, ifade tarzları ve tahliller de Ferrâ'nın sıklıkla değindiği ve Arap toplumunda örnekler sunarak gerekçelendirmeye çalıştığı değerlendirmeler arasında bulunmaktadır. ${ }^{79}$

\section{Sonuç ve Öneriler}

Şüphesiz ki dilin doğru bir şekilde öğrenilmesi gramer üzerinden gerçekleştirilmekte, belirlenen kurallar ve normlar bu sayede öğrenilebilmektedir. Özellikle belli bir dîne ait metinlerin o dine yabancı sayılanlar tarafından doğru bir şekilde anlaşılmasını sağlamada gramer ilminin önemi tartışılmazdır. Bundan dolayı her kadim kültürde olduğu gibi Arap

\footnotetext{
77 Muhammed b. Cerîr et-Taberî, Câmiu'l-beyânan tevîli âyi'l-Kurân, thk. Abdullah b. Abdulmuhsin et-Türkî̀Abdussened Hasan Yemâme (Kahire: Dâru Hecr, 1422/2001), 5/250, 251.

78 Mekkî b. Ebî Tâlib, el-Keşf'an vücûhi'l-ḳırââti's-seb've ilelihâ ve hucecihâ, thk. Muhyiddîn Ramazan (Beyrut: Müessesetü'r-Risâle, 1404/1984), 1/337.

79 Ferrâ, Ma'âni'l- Kurân, 1/ 89, 129, 189, 214, 218, 233, 261, 264; 2/6, 7, 15, 18, 201, 390, 391, 393; 3/24, 42, 78, 80, 90, 114, 130, 137, 157, 158, 206, 209, 219, 224, 238, 272, 289.
} 
kültüründe de dil diğer alanlara göre daha fazla önemsenmiş ve incelenmeye değer görülmüştür.

Arap coğrafyasında ilk dönemlerde gramer ile ilgili yürütülen faaliyetlere bakıldığında gramerin belli bir bölge, kabile ve lehçe özelinde irdelenmediği gibi bu ilimde otorite olarak kabul edilen şahısların tekeline bırakılmadığı da görülmektedir. Kayıt altına alınmış bir şekilde günümüze kadar ulaşan Sîbeveyhi'nin 'el-Kitâb' isimli eseri ile ilk dönem dilci ve edebiyatçıların yazmış oldukları kitaplarda değinilen konular, başvurulan örnekler ve yapılmış olan bireysel tahliller aracılığıyla böyle bir sonuca rahatlıkla varılabilir. Özellikle dil âlimlerince bazı âyetlerin tefsiri yapılırken sadece gramer kurallarına bağlı kalınmamış, sıklıkla Arap toplumunda kullanılan ifade tarzları ve kullanım biçimlerine atıfta bulunulmuştur. Yani Arapların bulunduğu bir coğrafyaya gönderilen kutsal kitabın içerik ve dil bakımından onların günlük konuşmalarından bağımsız olmadığı mesajı bazı âyetlerin gramatik ve semantik tahlili üzerinden verilmeye çalışılmıştır.

Aslında toplumların kabulüne binâen kelimelerin yeni anlamlar kazandığı tartışmaya bile açık değilken binlerce yıl öncesine ait dînî veya edebî metinlerin sadece gramerle çözülmeye çalışılması noktasında ortaya çıkan gayr-ı makul yaklaşımlar ve cevaplanması gereken soru işaretleri varken Arap gramerinin kaynak alanlarının sınırlandırılmasına gidilmesi rasyonel bir yaklaşım olmayacaktır. Bu yüzden oldukça eski bir dönemde kaleme alınmış edebî veya kutsal metinlerin o dönemin dil kültüründen koparılmamasına dikkat edilmeli, gramatik, etimolojik ve semantik tahlillerin özelde Arap toplumunun konuştuğu dile genelde sosyo-kültürel dinamizme tezatlık arz etmemesine özen gösterilmelidir. Ayrıca bu tür yaklaşımlar gramerden bir ödün verme değil, geniş dayanak çerçevesinden yararlanma olarak değerlendirilmelidir. Aksi bir bakış açısının akademi ve ilmî gelişime herhangi bir katkı sunmayacağı da açıtır. 


\section{Kaynakça}

Abdülvâhit, Muhammed Edîb. el-Mu'cem fi'l-esâlîbi'l-İslâmiyye ve'l-'Arabiyye. Riyad: Mektebetü'l-'Abîkân, 1420/1999.

Aksan, Doğan. Her Yönüyle Dil: Ana Çizgileriyle Dilbilim. Ankara: Türk Dil Kurumu Yayınları, 6. Basim, 2015.

Âmidî, Hasen b. Bişr. el-Mü'telif ve'l-muhtelif. thk. Fritz Krenkow. Beyrut: Dârü'l-Cîl, $1411 / 1991$.

Avn, Hasan. el-Lügatu ve'n-naḥv. b.y. Câmi'atü'l-İskenderiye, 1952.

Cengiz, Emin. Endülüs Tefsirinde Filolojik Yaklaşımlar İbn Eb̂̂ Zemenin Örneği. ed. İbrahim Baz, Yaşar Acat. Mardin: Şırnak Üniversitesi Yayınları, 2018.

Çıkar, Mehmet Şirin. Kıyas Bir Nahiv Usûl İlmi Kaynă̆ı. Van: Ahenk Yayınları, 2007.

Çıkar, Mehmet Şirin. Temel Kaynakları Bağlamında “İlmü’l-Edeb” Terimi ve İçeriği”. NÜSHA Şarkıyat Araştırmaları Dergisi, 5/19, (2005), 48-57.

Dilaçar, Agop. Gramer: Tanımı, Adı, Kapsamı, Türleri, Yöntemi, Eğitimdeki Yeri ve Tarihçesi. Ankara: Türk Tarih Kurumu Basım Evi, 2. Basım, 1989.

Ebû Hayyân, Muhammed b. Yûsuf b. Hayyân. el-Bahrü̈l-muhîț. thk. Adil Ahmed Abdülmevcut-Ali Muhammed Muavvid. 8 Cilt. Beyrut: Dâru'l-Kutubi'l-'İlmiyye, 1413/1993.

Fehrî, İbrahim b. Ebi'l-Hasan Ali b. Ahmed. Kenzü'l-küttâb. thk. Hayat Kâre. 2 Cilt. Birleşik Arap Emirlikleri: el-Mecma'u'l-'Illmî, 1425/2004.

Ferrâ, Yahyâ b. Ziyâd. Ma'âni'l- Kur'ân. thk. Muhammed Ali en-Neccâr-Ahmed Yusuf Necâtî. 3 Cilt. Beyrut: Âlemu'1-Kutub, 3. Basım, 1403/1983.

Feyyûmî, Ahmed b. Muhammed b. Alî. Kâmûsu'l-misbâhi'l-münîr fî gaarîbi'ş-şerhịil-kebîr li'rRâfi 'î. Beyrut: Dâru'l-Fikr li't-Tabbâ' ve'n-Neşr, 1435/2014.

Gül, Gülbahar. "Birey Toplum Eğitim ve Öğretmen”, Hasan Ali Yücel Ĕgitim Fakültesi Dergisi 1, (2004), 223-236.

Hafâcî, Şihâbüddîn Ahmed b. Muhammed. Şerḥu Dürreti'l-ġavvâș. thk. Abdulhafiz FerağlîAli el-Karnî. Beyrut: Dâru'l-Cîl, 1417/1996.

Hamevî, Yâkūt b. Abdillâh. Mu'cemü'l-üdebâ. thk. İhsan Abbas. 7 Cilt. Beyrut: Dârü'l-Garbi'lİslâmî, 1993.

Hudson, D. İlmü'l-lügati'l-ictimâ̂̂, çev. Mahmud Ayyâd Kahire: Âlemü'l-Kutub, 2. Basım, 1990.

İbn Abdürabbih, Ahmed b. Muhammed. el- '̇keü̈l-ferîd. thk. Mufîd Muhammed Kamîha. 9 Cilt. Beyrut: Dâru'l-Kutubi'l-'İlmiyye, 1404/1983.

İbn Âkîl, Abdullah b. Abdirrahmân b. 'Akîl. Şerḥu İbn 'Aḳil 'alâ Elfiyyeti İbn Mâlik, thk. Muhammed Muhyiddin Abdülhamît. 4 Cilt. Kahire: Dâru't-Turâs, 20. Basım, 1400/1980.

İbn Cinnî, Osmân b. Cinî el-Mevsılî. el-Hașẩ iș. thk. Muhammed Ali en-Necâr. 3 Cilt. Misır: el-Mektebetü'1-'İlmiyye, 1371/1952.

İbn Cinnî, Osmân b. Cinî el-Mevsılî. el-Münșıf. thk. İbrâhim Mustafa-Abdullah Emîn, 3 Cilt. Kahire: Dâru İhyâi't-Turâsi'l-Arabî, 1373/1954.

İbn Dürüsteveyh, Abdullah b. Ca'fer b. Dürüsteveyh. Tașhîhhu'l-Fașîh. thk. Muhammed Bedevî el-Mahtûn-Ramazan Abdüttevvâb. Kahire: 1425/2004.

İbn Fâris, Ahmed b. Fâris b. Zekeriyyâ. eș-Șâhibîf fì fiḳhi'l-luǵga. thk. Ömer Faruk et-Tabbâ'. Beyrut: Mektebetü'l-Ma'ârif, 1414/1993.

İbn Haldûn, Abdurrahmân b. Muhammed. Mukaddimetu ibn Haldûn. thk. Abdullah Muhammed ed-Dervîş. 2 Cilt. Dımaşk: Dârü'l-Belhî, 1425/2004. 
İbn Hişâm, Abdullāh b. Yûsuf b. Hişâm. Şerḥu Şüzûuri'ż-žeheb. thk. Muhammed Ebü'l-Fazl 'Aşûr. Beyrut: Dâru İhyâi't-Turâsi'l-'Arabî, 1422/2001.

İbn Mâlik, Muhammed b. Abdillâh b. Mâlik. Elfiyyetu İbn Mâlik. thk. Süleyman b. Abdülaziz el-`Uyûnî. Riyad: Mektebetu Dâri'l-Minhâc, 1428/2007.

İbn Manzûr, Muhammed b. Mükerrem. Lisânü'l-'Arab. 20 Cilt. Kuveyt: Dârü'n-Nevâdir, 1431/2010.

İbn Mukbil, Temîm b. Übey b. Mukbil. Dîvânu İbn muḳbil. thk. İzzet Hasan. Beyrut: Dârü'şşarki'l-Arabî, 1416/1995.

İbn Reşîk, el-Hasen b. Reşị̂ el-Kayrevânî. el- 'Umde fî̀ mehâsini'ş-şi 'r ve âdâbih ve naḳdih. thk. Muhammed Muhyiddin Abdulhamid. 2 Cilt. Suriye: Dâru'1-Cîl, 5. Basım, 1401/1981.

İbn Sîde, Alî b. İsmâîl. el-Muḥkem ve'l-muhîtụ̆l-a żam, thk. Abdülhamit Hendâvî. 11 Cilt. Beyrut: Dâru'l-Kutubi'l-'İlmiyye, 1421/2000.

İbnü'l-Enbâri, Abdurrahmân b. Muhammed. Lüma'u'l-edille fîuṣ̂li'n-nahvo. thk. Said elAfgânî. Suriye: Matba'atu'l- Câmi'ati's-Sûriye, 1377/1957.

İbnü'l-Enbârî, Muhammed b. el-Kāsım el-Enbârî. Kitâbü İżâhi'l-vakf ve'l-ibtidâ' fì Kitâbillâh. thk. Muhyiddîn Abdurrahman Ramazan. 2 Cilt. Dımaşk: Matbûât Mecmai'l-Lugati'1Arabiyye, 1391/1971.

İbnü'l-Hâcib, Osmân b. Ömer b. Ebî Bekr. el-İżâh fî şerhi'l-Mufașșal. thk. Mûsâ Binây el-Alîlî. 2 Cilt. Bağdad: Matba'atü'1-'Anî, 1402/1982.

İbnü'l-Haşşâb, Abdullāh b. Ahmed el-Haşşâb. el-Mürtecel fi şerhi'l-cümel. thk. Ali Hayder, Dimaşk: Mektebetu Macma'i'l-Luga'l-Arabiyye, 1392/1972.

İbnü'l-Müeddib, Muhammed b. Said. Dekâikü̈'t-tașrîf. thk. Hatim Salih ed-Dâmin, Dımaşk: Dârü'l-Beşâir, 1425/2004.

İbnü's-Serrâc, Muhammed b. es-Serî. el-Uș̂ul fi'n-naḥv. thk. Abdülhüseyin el-Fetlî. Beyrut: Müessesetü'r-Risâle, 3. Basım, 1417/1996.

İbnü'ş-Şecerî, Hibetullah b. Alî b. Muhammed. Emâlı̂ ibni'ş-Şecerî. thk. Muhammed etTannâhî. 3 Cilt. Kahire: Mektebetü'1-Hânecî, 1413/1992.

İnanç, Yonis. "Nahiv İlmi Açısından Temîm Lehçesinin İstişhâd Değeri”. Sakarya Üniversitesi İlahiyat Fakültesi Dergisi 17/31 (Haziran 2015), 1-25. https://doi.org/10.17335/sakaifd.219892

Kaplan, Mehmet. Kültür ve Dil. İstanbul: Dergâh Yayınları, 36. Basım, 2019.

Karagöz, Mustafa. Dilbilimsel Tefsir ve Kur'an-ı Anlamaya Katkısı: Hicri İlk Üç Asır. Kayseri: Erciyes Üniversitesi, Sosyal Bilimler Enstitüsü, Doktora Tezi, 2009.https://tez.yok.gov.tr/UlusalTezMerkezi/240794

Kur'ân Yolu, Erişim 20 Nisan 2020. https://kuran.diyanet.gov.tr

Kurtubî, Muhammed b. Ahmed. el-Câm' li ạ̣kâmi'l-Kur'ân. thk. Abdullah b. Abdulmuhsin etTürkî. 12 Cilt. Beyrut: Müessesetü'r-Risâle, 1427/2006.

Mansûr b. Felâh en-Nahvî, İbn Felâh, el-Muğgn̂fi'n-naḥv. thk. Abdurrezzâk Abdurrahman esSa'dî. 3 Cilt. Mekke: Ümmülkura Üniversitesi, 1404/1984.

Mekkî b. Ebî Tâlib, el-Keşf 'an vücûhi'l-ḳıâ'âti's-seb' ve 'ilelihâ ve hucecihâ. thk. Muhyiddîn Ramazan. 2 Cilt. Beyrut: Müessesetü'r-Risâle, 3. Basım, 1404/1984.

Müberred Muhammed b. Yezîd. el-Kâmil. thk. Muhammed Ahmed ed-Dâlî. 4 Cilt. Beyrut: Müessesetü'r-Risâle, 2. Basım, 1412/1992.

Müberred, Muhammed b. Yezîd. el-Muḳteḍab. thk. Muhammed Abdülhâliḳ Uzayme. 4 Cilt. Kahire: 1415/1994.

Önler, Zafer. Dil ve Kültür Üzerine Yazılar. İstanbul: Dergâh Yayınları, 2019.

Perek, Faruk Zeki. Eski Çă̆da Dilbilgisi Araştırmaları: Gramerin Doğuşu. İstanbul: Edebiyat Fakültesi Basımevi, 1961. 
Râzî, Muhammed b. Ömer. Mefâtîhu'l-ġayb. 32 Cilt. Beyrut: Dâru'l-Fikr, 1401/1981.

Sa‘leb, Ahmed b. Yahyâ eş-Şeybânî. Mecâlisu Sa`leb. thk. Abdüsselam Muhammed Harûn. 7 Cilt. Mısır: Dâru'l-Ma'ârif, 2. Basım, 1960.

Safedî, Halîl b. İzziddîn Aybeg b. Abdillâh. el-Vâfî̀ bi'l-vefeyât. thk. Ahmed el-ArnavutMustafa Türkî. 29 Cilt. Beyrut: Dâru İhyâi't-Turâsi'l-'Arabî, 1420/2000.

Salan, Musa. Tarihî Kuzeybatı Kıpçakçası Fiil Yapım Ekleri ve Tarihî Karşılaştırmalı Etimolojik Fiil Sözlüğü. İstanbul: Hiperlink Eğitim İletişim Yayıncılık, 2019.

Sîbeveyhi, 'Amr b. Osman. el-Kitâb. thk. Abdusselâm Muhammed Harun. 5 Cilt. Kahire: Mektebetu'l-Hânecî, 1408/1988.

Süyûtî, Abdurrahmân b. Ebî Bekr. el-Müzhir fì 'ulûmi'l-luğa ve envấihâ. 2 Cilt. Kahire: Mektebetü'd-Dâri't-Turâs, 3. Basım, 2008.

Süyûtî, Abdurrahmân b. Ebî Bekr. el-Behcetü'l-merżıyye, thk. Ali es-Seyyâh. 2 Cilt. b.y. Dâru'l'Ulûm, 1433/2012.

Taberî, Muhammed b. Cerîr b. Yezîd. Câmi 'u'l-beyân 'an te'vîli âyi'l-Kur'ân. thk. Abdullah b. Abdulmuhsin et-Türkî-Abdüssened Hasan Yemame. 26 Cilt. Kahire: Dâru Hecr, $1422 / 2001$.

Tantâvî, Ahmed. Neş'etü'n-naḥv ve târîhu eşheri'n-nuhât. Misır: Dârü'l-Ma'ârif, 1995.

Temel, Ali. Dilbilimsel Tefsirlerde Kırâatlere Yaklaşım. Ankara: Ankara Üniversitesi, Sosyal Bilimler Enstitüsü, Doktora Tezi, 2015. UlusalTezMerkezi/tezSorguSonucYeni.jsp 407341

Terabichi, Georges. Nakkd-u naḳdi'l-akli'l-'Arabî. Beyrut: Dâru's-Sâkî, 1998.

Ukberî, Abdullāh b. el-Hüseyn b. Abdillâh. el-Mesâ'ilü'l-hilâfiyye fi'n-nahọ. thk. Abdulfettâh Selîm. Kahire: Mektebetü'1-Âdâb, 3. Basım, 1428/2007.

Ukberî, Abdullāh b. el-Hüseyn b. Abdillâh. et-Tebyîn 'an mezâhibi'n-nahviyyîne'l-Bașriyyîn ve'lKûfiyyîn. thk. Abdurrahman el-Useymîn. Beyrut: Dâru'l-Garbi'l-İslâmî, 1416/1995.

Zebîdî, Muhammed el-Murtazâ b. Muhammed b. Abdirrezzâk. Tâcü'l-'arûs min cevâhiri'lKāmmûs. thk. Abdülkerim el-Azbâvî, 40 Cilt. Kuveyt: el-Meclisü'l-'İlmî li's-Sekâfe, $1421 / 2000$.

Zeccâc, İbrâhîm b. es-Serî b. Sehl. Me 'âni'l-Kur'ân ve i'râbüh. thk. Abdülcelil Abduh Şelebî. 5 Cilt. Beyrut: Âlemu'l-Kutub, 1408/1988.

Zeccâcî, Abdurrahmân b. İshâk. el-İ̇âh fị 'ileli'n-nahọ. thk. Mâzin el-Mübârek. Beyrut: Dâru'n-Nefâis, 3. Basım, 1399/1979. 